\title{
THE METABOLISM OF LEUCOCYTES FROM NORMAL AND LEUKEMIC BLOOD
}

\author{
By L. J. SOFFER AND M. M. WINTROBE
}

(From the Medical Clinic, Johns Hopkins University and Hospital, Baltimore)

(Received for publication February 23, 1932)

Warburg's studies (9) on the metabolism of tumor cells have stimulated great interest in similar studies of the blood corpuscles. Grafe (1) has shown that leucocytes consume considerable amounts of oxygen. Although it had previously been known that they are capable of splitting sugar, it remained for Levene and Meyer (2) to demonstrate their ability to produce lactic acid from dextrose. Maclean and Weir (3), in comparing the glycolytic power of leucocytes and erythrocytes, found that the former have a glycolytic power several hundred times greater than the latter. Metabolic studies have been carried out with a view of determining the oxygen consumption and sugar destruction of leucocytes, and of mature as compared with that of immature white corpuscles. These studies have yielded contradictory results. Daland and Isaacs (4) as well as Glover, Daland and Schmitz (5) concluded that mature leucocytes consume greater amounts of oxygen than do immature white cells. The latter investigators (5) also concluded that the glycolytic function of the leucocytes, at least in whole blood, is inversely proportional to the maturity of the cells. These findings could not be confirmed by Barron and Harrop (6), who emphasized the depressing effect of concentration on both the oxygen consumption and sugar destruction of white blood cells.

The object of this paper is to study further, with improved technic, the effect of cell maturity and cell concentration on the metabolic activity of leucocytes.

\section{METHOD}

Whole blood containing varying numbers of leucocytes from patients suffering from myeloid and lymphoid leukemia and from cases of leucocytosis due to various causes was studied. Arterial blood was collected in most instances. This was done to avoid the injury to the cells which results from manipulation incidental to aeration of venous blood. Samples were collected in purified heparin and immediately studied. Oxygen consumption was determined in Barcroft-Warburg manometers at $37.5^{\circ} \mathrm{C}$., the readings being taken at 5 minute intervals for 30 minutes. Sugar determinations were made immediately before placing the samples in the microrespirometers, and directly after the experiment. The samples to be studied were subjected to as little manipulation as possible and centrifuging was entirely avoided in view of its damaging effects on the respiration and to a lesser extent on the glycolytic activity of the white blood cells, as demonstrated by Fujita (7). Varying 
concentrations of the cells were obtained by diluting specimens of blood with plasma which had previously been obtained by centrifuging another sample of blood from the same patient. In those instances in which anaerobic metabolism was studied, suppression of aerobic respiration was produced by the use of $0.005 \mathrm{M}$. KCN.

In order to have as complete information as possible concerning all factors in the blood which might influence the degree of metabolic activity the following studies were carried out: erythrocyte, leucocyte, platelet, and reticulocyte counts, as well as fresh blood and stained smear examinations. All blood specimens for these examinations were taken from the samples actually used in the metabolic studies. Erythrocyte and leucocyte counts were made on each blood dilution. The other hematologic examinations were carried out only once on each sample since, by the technic employed, the relative numbers of reticulocytes, platelets, and the various types of leucocytes, remained the same in subsequent dilutions.

All values were recorded in absolute numbers, since it was felt that these serve better as indices of the constituents of the sample than do relative values. In the classification of the leucocytes, the number of myeloblasts, myelocytes, juvenile (meta-myelocytes) and segmented granulocytes, as well as lymphoblasts, young and adult lymphocytes, and monocytes were separately recorded. Eosinophilic and basophilic leucocytes were grouped with the neutrophilic myelocytes, juvenile and segmented forms, depending on their degree of maturity. In the examination of the blood smear, particular attention was paid to the number of nucleated and polychromatophilic red corpuscles since Harrop (8) has shown that immature erythrocytes consume considerable amounts of oxygen.

In the earlier experiments especially, repeated fresh blood and fixed blood specimens were examined before and after the metabolic studies were carried out, in order to determine whether or not these manipulations caused injury to the leucocytes. Degree of motility and integrity of structure were the criteria employed in the examination of the fresh specimens, and morphology and staining reaction were noted in the fixed and stained preparations. In no instance could it be determined by the methods used that significant injury had been done to the cells. In the first experiment each dilution was examined in this way. In subsequent experiments these examinations were made less and less frequently, as no evidence of damage was discovered.

The cases were classified in groups according to the predominating type of leucocyte present. The classification adopted for the group of myeloid leukemias and "myeloid reactions" was essentially that employed by Glover, Daland and Schmitz (5), namely: Group I-Cases in which polymorphonuclear and juvenile granulocytes predominated. In this group are found all of the "myeloid reactions." Group II-Cases in which large numbers of myelocytes were encountered together with a moderate number of segmented granulocytes and few or no myeloblasts. These were chiefly derived from the cases of untreated or incompletely treated chronic myeloid leukemia. Group IIICases in which myeloblasts and early myelocytes predominated. In this group are classed the cases of acute myeloblastic leukemia. With one exception (Case Fl) the granulocytes composed 90 per cent or more of all the leucocytes present. The "myeloid reactions" consist of the cases of leucocytosis due to causes other than leukemia.

In the lymphoid series, lymphocytes made up 96 per cent or more of all the leucocytes present. These cases were divided in two groups, Group I consisting of those in which practically all of the lymphocytes were adult forms 
L. J. SOFFER AND M. M. WINTROBE

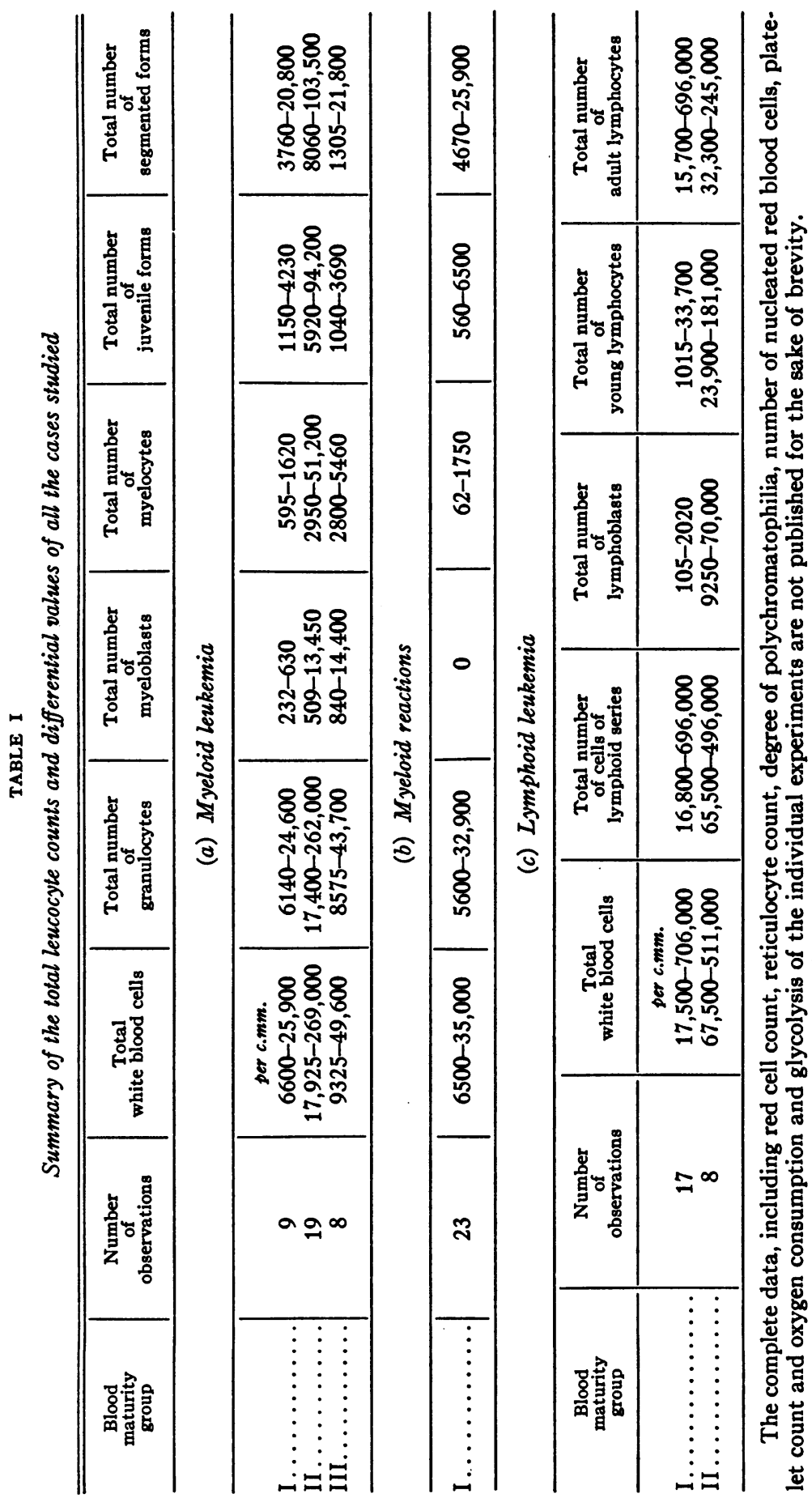


and Group II being made up of those cases in which a substantial number of young lymphocytes and especially lymphoblasts were found. Size was not considering to be an essential criterion of age but reliance was put instead on such characteristics as structure of nuclear chromatin, nucleoli, and basophilia of cytoplasm. Wiseman (12) has recently demonstrated the importance of these criteria.

In order to make comparison possible, constants for oxygen consumption havé been calculated for given units of time and in relation to the number of cells in the sample. Constants ${ }^{1}$ have been determined for both 10 minute $\left(K_{1}\right)$ and 30 minute $\left(K_{2}\right)$ periods because of differences which were observed in the amount of oxygen consumed at these time intervals. Likewise a constant has been determined to express glycolytic activity $\left(K_{G}\right) .^{2}$

\section{RESULTS}

In studying the oxygen consumption of the leucocytes it was at once evident that the amount of oxygen consumed per 5 minute period became less the longer the experiment proceeded. Thus, the maximum consumption per unit of time occurred during the first 10 minutes. This was followed by an appreciable decrease during the next 20 minutes (Figure 1). For this reason oxygen consumption constants were calculated for 10 al 130 minute periods. Fujita (7) found somewhat similar results in studying rat blood leucocytes.

\section{Influence of concentration on $\mathrm{O}_{2}$ consumption and glycolysis}

Our observations, 84 in all, made on samples with leucocyte counts which ranged from 6,500 to 706,000 per c.mm. demonstrate the depressing effect of concentration on the metabolism of leucocytes (Figures 2 and 3). In Table II the readings in the cases of myeloid leukemia and "myeloid reaction" have been arranged in groups according to the magnitude of their leucocyte counts. The data concerning the cases of lymphoid leukemia are presented in Table IV $(b)$. It is evident from an examination of these charts and tables that the degree of oxygen consumption $\left(K_{1}, K_{2}\right)$ is inversely proportional to the concentration of the leucocytes. This is true of all three groups considered and of the individual cases as well, with few exceptions.

The data for oxygen consumption have been analyzed statistically. Fifty-one and fifty-four determinations are available for $K_{1}$ and $K_{2}$ respectively. The analysis indicates significant correlation between leucocyte concentration and oxygen consumption but the reservation must

$$
{ }^{1} K=\frac{\text { Cubic millimeters of } \mathrm{O}_{2} \text { consumed per } 2 \text { cc. blood }}{\text { Cell concentration (in thousands) } \times \text { time (hours) }} .
$$

Two c.c. of blood were used in all metabolic studies because the apparatus employed is calibrated for this quantity of blood.

$$
{ }^{2} K_{G}=\frac{\text { Milligrams of sugar destroyed per hour per } 2 \mathrm{cc} \text {. blood }}{\text { Cell concentration (in thousands) }} .
$$


here be made that where such a relatively small number of observations is considered, too great stress must not be laid on the values obtained. The correlation in both cases is nonlinear. The ratio of correlation $(\eta)$ between $K_{1}$ and leucocyte count is .7492 which becomes .7010 when corrected for number of arrays. The number of arrays used in the calcu-

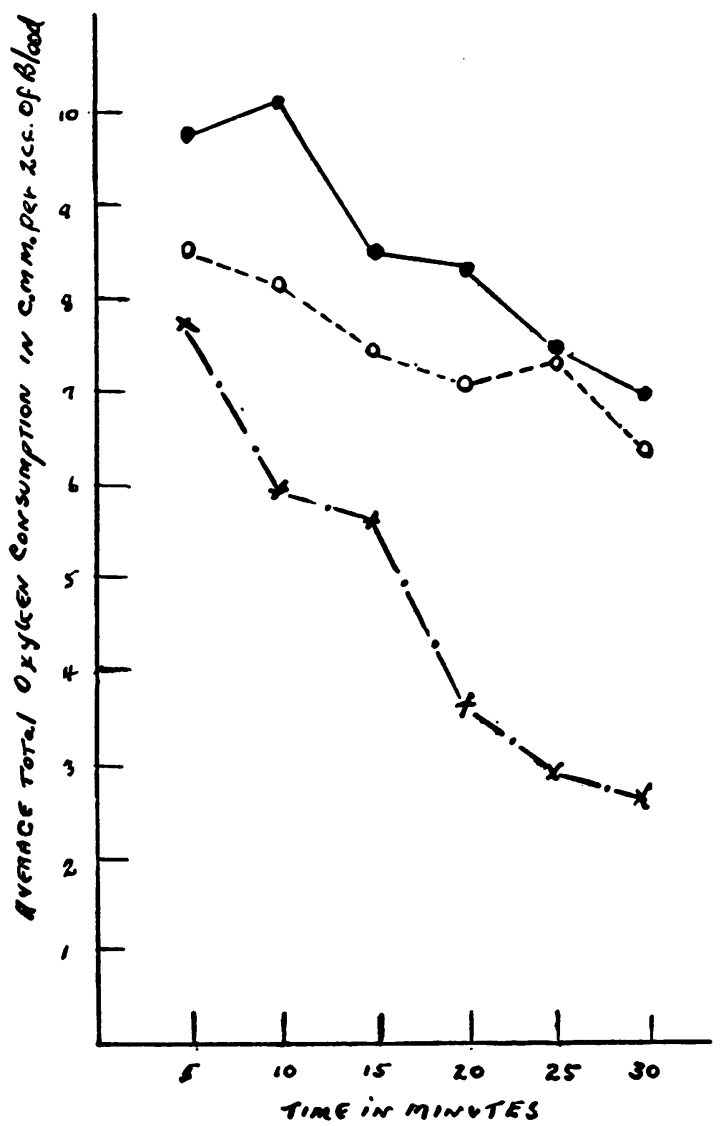

Fig. 1. The Amount of Oxygen Consumed by Leucocytes from Normal and Leukemic Blood Measured at 5 Minute Intervals. AverAGE of All Experiments.

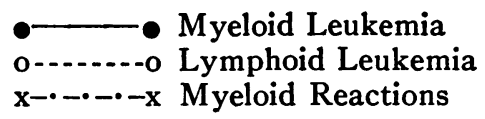

lation of this constant was 10 and therefore $(K-1) / N$, or the mean value of $\eta$ where correlation is actually zero, is .1765 . That the ratio of correlation between magnitude of leucocyte count and $K_{1}$ is probably significant is shown by the fact that $\eta$ differs from $\sqrt{(K-1) / N}(=.4202)$ by more than $1.7 / \sqrt{N}(=.2380)$, a criterion which has been set up by Pearson. 
Likewise the correlation ratio for $K_{2}$ and leucocyte count appears to be significant. $\eta$ is .8730 , or .8458 when corrected for number of arrays. In the analysis 11 arrays were employed and therefore $\eta$ for a totally uncorrelated population is .2040 . In this case $\eta$ differs from $\sqrt{(K-1) / N}(=.4517)$ by considerably more than $1.7 / \sqrt{N}(=.2313)$.

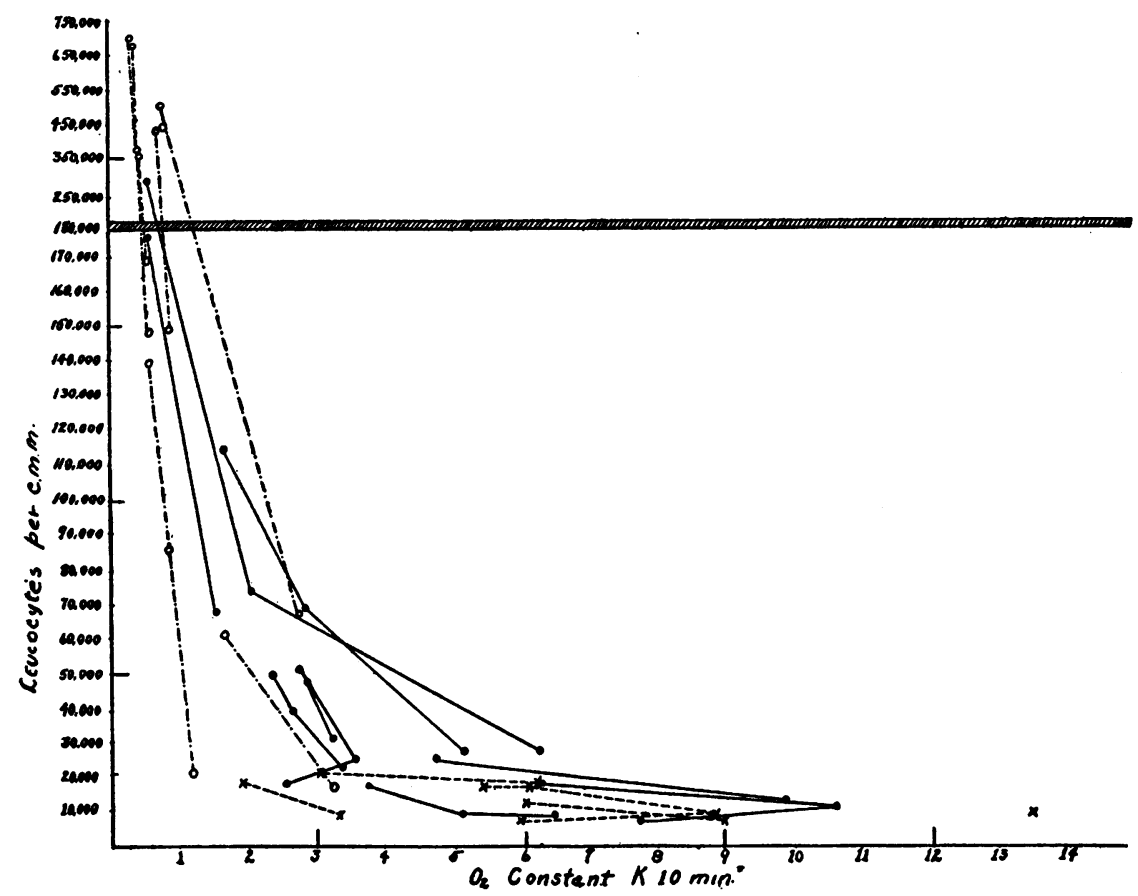

Fig. 2. Relation of Number of Leucocytes to Oxygen Consumption Constant- $K_{1}$ (10 Minutes).

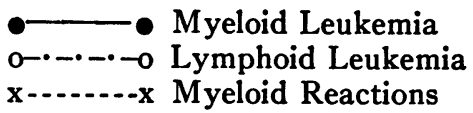

The lines in this and in figures 3,4 , and 5 join observations carried out on the same blood at different dilutions. Above 180,000 leucocytes per c.mm. the chart has been abbreviated.

$$
{ }^{*} K_{1}=\frac{\text { c.mm. } \mathrm{O}_{2} \text { per } 2 \mathrm{cc} \text {. blood }}{\text { cell concentration (in thousands) } \times \text { time (10 minutes) }} \text {. }
$$

It was not considered worth while to analyze the values for glycolysis in this way since only 36 and 28 determinations were made of aerobic and anaerobic glycolysis respectively.

The correlation between oxygen consumption and leucocyte concentration is evidently not linear. There appeared to be a rapid decrease in the amount of oxygen consumed as the leucocyte count rose to approx- 
imately 30,000 , following which a less rapid diminution was observed up to about 70,000 leucocytes. Beyond this point the depressing effect of concentration was so great that oxygen consumption was diminished relatively little in proportion to large differences in leucocyte counts.

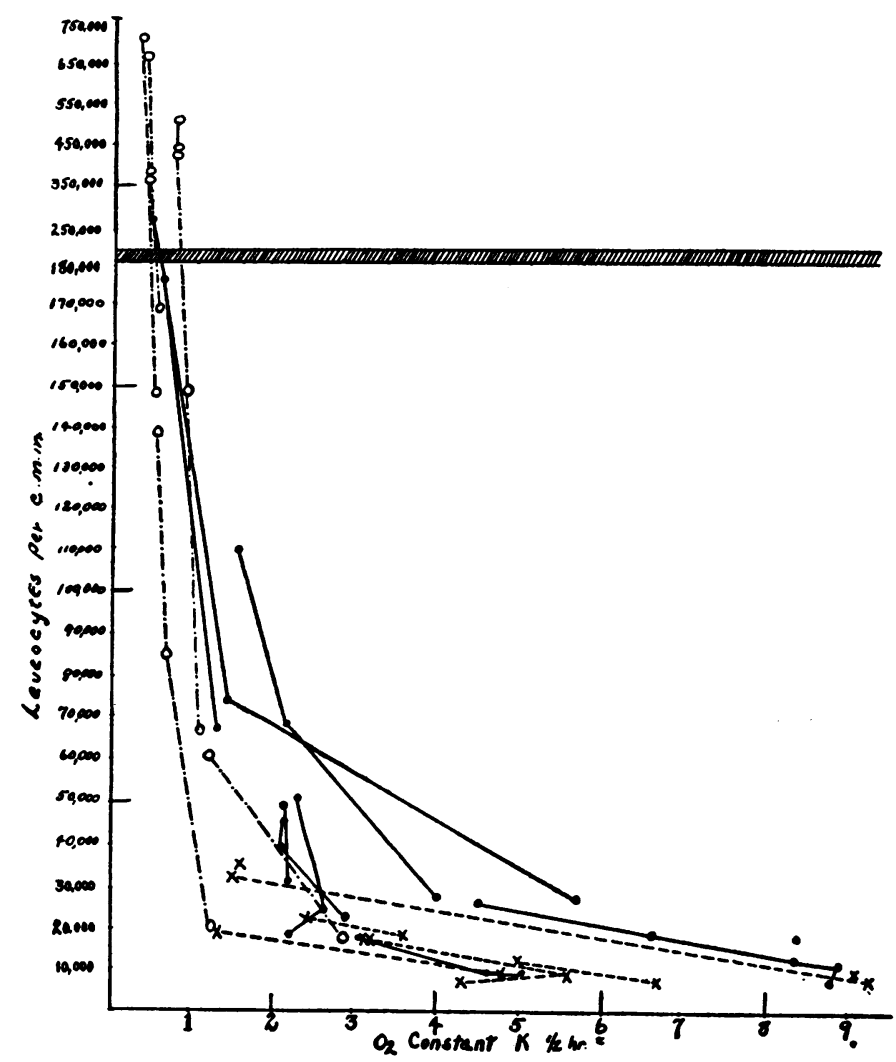

Fig. 3. Relation of Number of Leucocytes to Oxygen Consumption ConSTANT- $K_{2}$ (30 MinUtes).

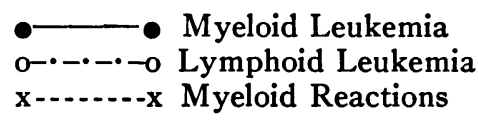

$$
{ }^{*} K_{2}=\frac{\text { c.mm. } \mathrm{O}_{2} \text { per } 2 \mathrm{cc} \text {. blood }}{\text { cell concentration (in thousands) } \times \text { time (30 minutes) }} \text {. }
$$

The correlation between $K_{2}$ and the leucocyte count is greater than that between $K_{1}$ and the number of white corpuscles. In other words the longer the experiment continues the greater is the depressing effect of the number of leucocytes on the oxygen consumption. This is apparent in comparing Figures 2 and 3 and is indicated by the greater value of the correlation ratio for $K_{2}$ as compared with that for $K_{1}$. It is evident from 


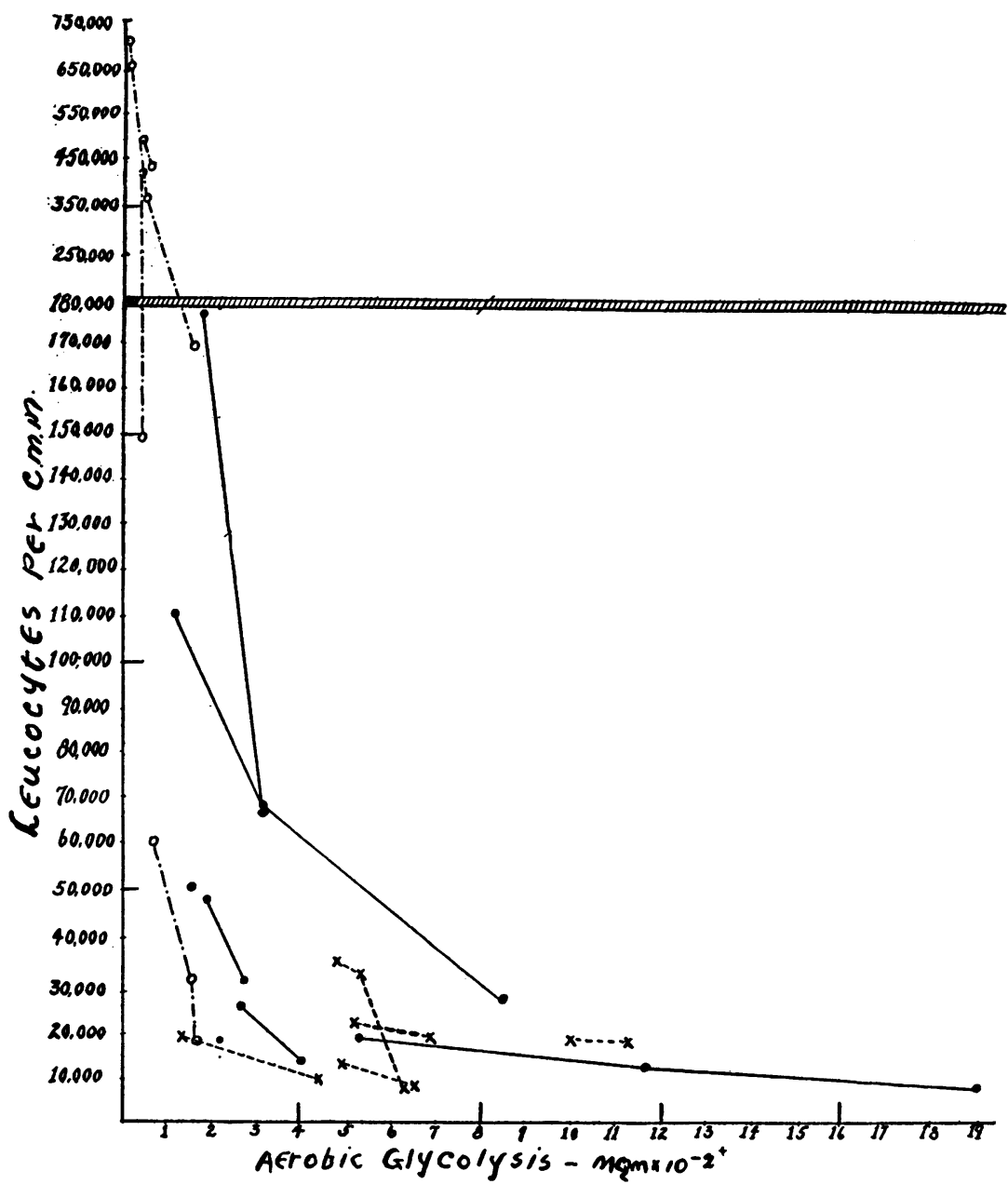

Fig. 4. Relation of Number of Leucocytes to Aerobic Glycolysis$\operatorname{Mgm}\left(\times 10^{-2}\right)$.

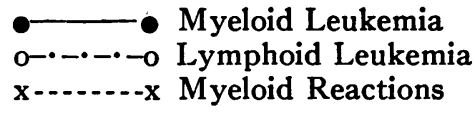

$\dagger K_{G}=\frac{\mathrm{mgm} \text {. of sugar per hour per } 2 \text { cc. blood }}{\text { cell concentration (in thousands) }}$. 


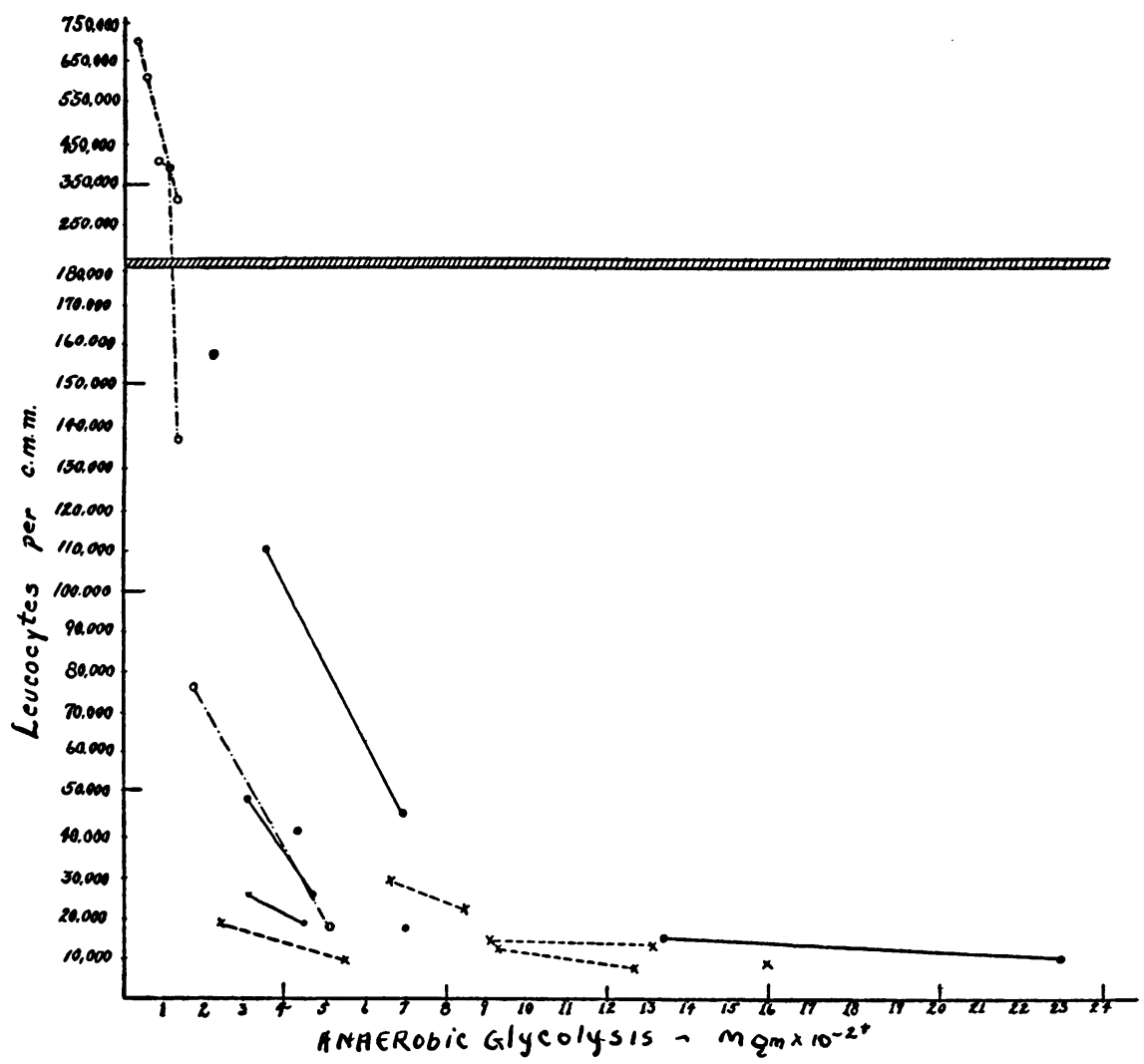

Fig. 5. Relation of Number of Leucocytes to Anaerobic Glycolysis$\operatorname{Mgm}\left(\times 10^{-2}\right)$.

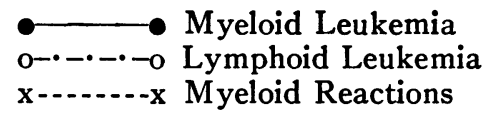

$\dagger K_{G}=\frac{\mathrm{mgm} \text {. of sugar per hour per } 2 \mathrm{cc} \text {. blood }}{\text { cell concentration (in thousands) }}$. 
examination of Figures 4 and 5 and Tables II and IV (b) that a similar depressing influence is exercised by leucocyte concentration on sugar metabolism. This may perhaps be explained by the increase in $\mathrm{pH}$ due to the accumulation of lactic acid.

TABLE II

Observations on oxygen consumption and glycolysis in myeloid leukemias and "myeloid reactions" grouped according to magnitude of leucocyte counts

\begin{tabular}{|c|c|c|c|c|c|}
\hline \multirow{2}{*}{$\begin{array}{c}\text { Average } \\
\text { white blood cells }\end{array}$} & \multirow{2}{*}{$\begin{array}{c}\text { Number of } \\
\text { observations }\end{array}$} & \multicolumn{2}{|c|}{$\mathrm{O}_{2}$ consumption constant $*$} & \multicolumn{2}{|c|}{ Glycolysis † } \\
\hline & & $\underset{\text { period }}{K_{1}^{K_{1}}}$ & $\underset{\text { period }}{\stackrel{K_{2}}{30}}$ & $\begin{array}{r}\text { Aerobic } \\
\times 10^{-2}\end{array}$ & $\begin{array}{c}\text { Anaerobic } \\
\times 10^{-2}\end{array}$ \\
\hline $\begin{array}{r}\text { per c.mm. } \\
9,734 \\
21,462 \\
41,075 \\
65,265 \\
165,540\end{array}$ & $\begin{array}{r}20 \\
20 \\
8 \\
4 \\
5\end{array}$ & $\begin{array}{l}7.88 \\
4.50 \\
2.81 \\
2.30 \\
0.92\end{array}$ & $\begin{array}{l}6.75 \\
3.48 \\
1.89 \\
1.79 \\
0.87\end{array}$ & $\begin{array}{l}7.68 \\
6.38 \\
3.66 \\
2.52 \\
1.40\end{array}$ & $\begin{array}{r}12.80 \\
4.53 \\
4.70 \\
\\
2.84\end{array}$ \\
\hline
\end{tabular}

* $\frac{\text { c.mm. } \mathrm{O}_{2} \text { per } 2 \text { cc. of blood }}{\text { cell concentration (in thousands) } \times \text { time (hours) }}$

$\dagger \frac{\text { mgm. sugar per hour per } 2 \mathrm{cc} \text {. of blood }}{\text { cell concentration (in thousands) }}$.

II. Metabolism of the different types of cells

Barron and Harrop (6) found no differences in the metabolism of granulocytes from cases of leucocytosis as contrasted to that of cells from myeloid leukemia. Glover and his associates (5) on the other hand, concluded that the metabolism of normal white blood cells is more active than that of relatively mature cells from patients with leukemia.

In view of the significant influence of concentration on metabolism of leucocytes, experiments in cases of leucocytosis and leukemia which had approximately the same white cell counts, have been compared (Table III). Both oxygen consumption and glycolysis were greater in the cases of leukemia than in the instances of leucocytosis, although the leucocyte counts were slightly lower in the latter group. These observations are the reverse of those of Glover and his co-workers. The differences are so small, however, that their significance is doubtful in view of the technical error of the methods employed.

A comparison of the cases of lymphatic leukemia with those of myeloid leukemia of similar leucocyte counts (Table III) indicates that the lymphoid cells consume less oxygen than do the granulocytes. The aerobic and anaerobic glycolysis of the myeloid cells was about twice as great as that of the leucocytes from the lymphoid leukemias. It is interesting to note that the volume of the granulocyte is about 3 to 5 times that of the lymphocyte. 
L. J. SOFFER AND M. M. WINTROBE

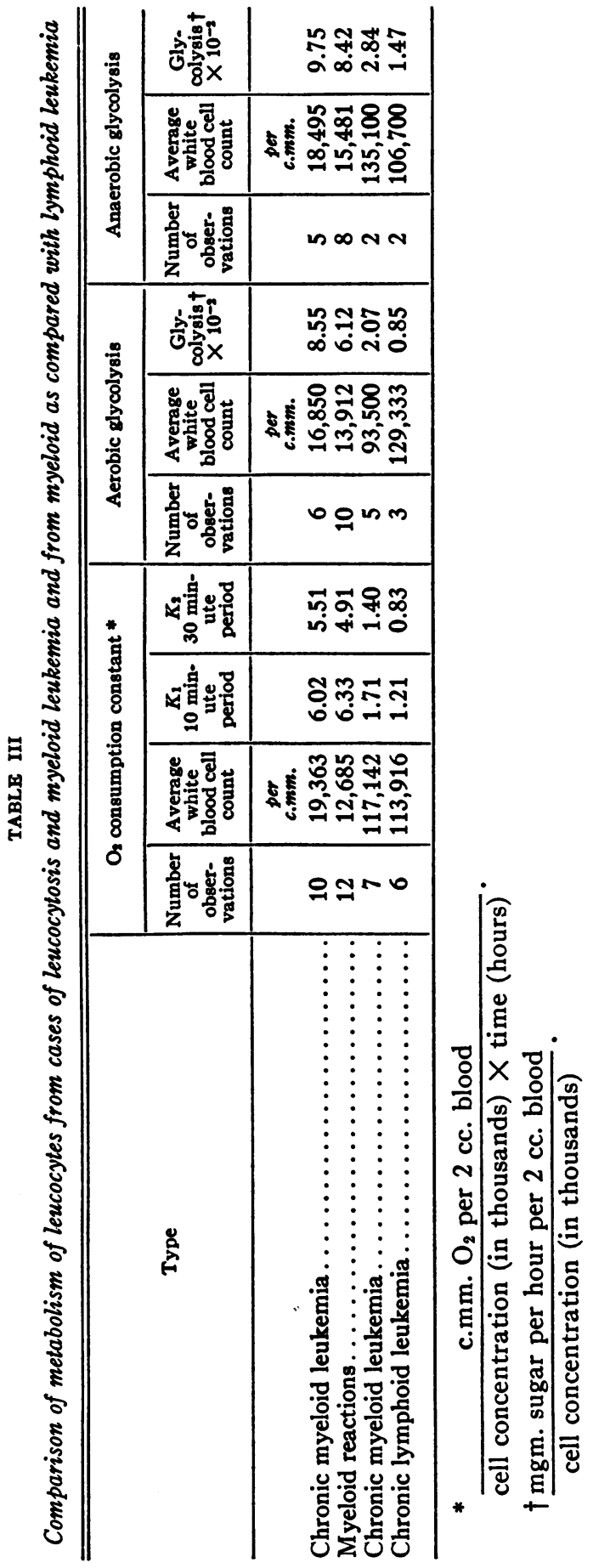




\section{Influence of maturity on metabolism}

The pronounced effect of concentration of leucocytes on their metabolism makes it difficult to determine the influence of any other factor. In Table IV our observations are arranged in groups according to the leucocyte counts and the degree of maturity of the cells. From examination of this table, it is apparent that metabolic activity is influenced by concentration of leucocytes regardless of the maturity of the cells. Comparison of different groups with approximately equal leucocyte counts shows that the differences are small in extent and occur in both directions. Thus, the oxygen consumption of the mature granulocytes (Group I) with an average leucocyte count of 13,668 is greater than that of an immature group (Group III) with an average count of 16,741. On the other hand, the oxygen consumption of the Group II series with an average count of 24,005 is greater than that of a Group I series with a count of 28,544 . As further indicating the influence of concentration rather than that of maturity, it should be observed that the respiration of the very immature group (Group III) with a leucocyte count of 16,741 is distinctly greater than that of the most mature group (Group I) with a count of 28,544 . A comparison of the respiratory function of the lymphocytes shows essentially the same results.

Unfortunately there is not a sufficient number of cases with comparable cell counts but of different maturity to make a similar comparison possible in regard to the relation of maturity to glycolysis. Nevertheless it appears from the data in Table IV that the degree of glycolysis varied inversely with the magnitude of the cell counts and was not related to the age of the cells. This is indicated by the cases in Group I. Despite the fact that the cells in this group were of the same degree of maturity, there was a wide variation in glycolytic activity which bore a constant inverse relationship to cell concentration. In 9 cases with an average count under 10,000 the aerobic glycolysis was $8.16 \mathrm{mgm} . \times 10^{-2}$ and the anaerobic glycolysis $14.84 \mathrm{mgm} . \times 10^{-2}$. In a series of 14 cases of this same group where the average count was 12,268 leucocytes, the aerobic and anaerobic glycolysis were $6.92 \mathrm{mgm} . \times 10^{-2}$ and $8.64 \mathrm{mgm} . \times 10^{-2}$ respectively. Finally, for 5 cases with counts between 20,000 and 30,000 and averaging 27,396 , the sugar consumption was least of all, being 3.89 $\mathrm{mgm} . \times 10^{-2}$ aerobically and $6.06 \mathrm{mgm} . \times 10^{-2}$ anaerobically.

\section{Effect of the number of red blood cells on the oxygen consumption of leucocytes}

Harrop (8) demonstrated that adult mammalian erythrocytes consume a definite but extremely small amount of oxygen. Although the amount which is thus consumed is not appreciable in comparison to the total oxygen consumption of the white cells, it was thought advisable to determine whether the red corpuscles, as oxygen carriers, influenced the 
TABLE IV

Relationship of metabolism to maturity of leucocytes

\begin{tabular}{|c|c|c|c|c|c|c|c|c|c|}
\hline$\underset{\text { rity }}{\text { Matu- }}$ & \multirow{2}{*}{$\begin{array}{l}\text { Number } \\
\text { of obser- } \\
\text { vations }\end{array}$} & \multirow{2}{*}{$\begin{array}{c}\text { Average } \\
\text { leucocyte } \\
\text { count }\end{array}$} & \multicolumn{2}{|c|}{$\begin{array}{l}\text { Oxygen consump- } \\
\text { tion constant } *\end{array}$} & \multirow{2}{*}{$\begin{array}{c}\begin{array}{c}\text { Matu- } \\
\text { rity }\end{array} \\
\begin{array}{c}\text { Group } \\
\text { number }\end{array}\end{array}$} & \multirow{2}{*}{$\begin{array}{l}\text { Number } \\
\text { of obser- } \\
\text { vations }\end{array}$} & \multirow{2}{*}{$\begin{array}{l}\text { Average } \\
\text { leucocyte } \\
\text { count }\end{array}$} & \multicolumn{2}{|c|}{ Glycolysis † } \\
\hline $\begin{array}{l}\text { Group } \\
\text { number }\end{array}$ & & & $\underset{\text { utes }}{10 \mathrm{~min}-}$ & $\begin{array}{c}K_{2} \\
30 \text { min- } \\
\text { utes }\end{array}$ & & & & $\begin{array}{c}\text { Aerobic } \\
\text { mgm. } \\
\times 10^{-2}\end{array}$ & $\begin{array}{c}\text { Anaerobic } \\
\text { mgm. } \\
\times 10^{-2}\end{array}$ \\
\hline
\end{tabular}

(a) Myeloid series

\begin{tabular}{|c|c|c|c|c|c|c|c|c|c|}
\hline & & $\begin{array}{c}\text { per } \\
\text { c.mm. }\end{array}$ & & & & & $\begin{array}{c}\text { per } \\
\text { c.mm. }\end{array}$ & & \\
\hline & 17 & 13,668 & 6.80 & 5.30 & I. & 9 & 7,898 & 8.16 & 14.84 \\
\hline III . & 4 & 16,741 & 4.64 & 3.73 & I. & 14 & 15,268 & 6.92 & 8.64 \\
\hline Il . & 5 & 24,005 & 4.19 & 3.49 & III. & 2 & 21,350 & & 5.85 \\
\hline I. & 4 & 28,544 & 3.89 & 2.48 & I . . & 7 & 27,396 & 3.93 & 6.06 \\
\hline III & 1 & 48,700 & 2.84 & 2.12 & & & & & \\
\hline \multirow[t]{4}{*}{ II . } & 9 & 100,567 & 1.91 & 1.55 & & 1 & 27,500 & 8.51 & \\
\hline & & & & & III. & 2 & 30,700 & 2.73 & \\
\hline & & & & & III.... & 2 & 49,100 & 1.84 & 3.02 \\
\hline & & & & & & 9 & 92,600 & 2.08 & 4.19 \\
\hline
\end{tabular}

(b) Lymphoid series

\begin{tabular}{|c|c|c|c|c|c|c|c|c|c|}
\hline $\begin{array}{l}\text { I } \ldots \ldots \\
\text { II } \ldots \ldots \\
\text { I } \ldots \ldots \\
\text { I } \ldots \ldots \\
\text { II } \ldots \ldots \\
\text { I } \ldots \ldots\end{array}$ & $\begin{array}{l}2 \\
2 \\
4 \\
3 \\
3 \\
2\end{array}$ & $\begin{array}{r}18,812 \\
106,250 \\
109,000 \\
298,300 \\
462,700 \\
684,500\end{array}$ & $\begin{array}{l}2.23 \\
1.82 \\
0.91 \\
0.46 \\
0.75 \\
0.36\end{array}$ & $\begin{array}{l}2.05 \\
1.02 \\
0.75 \\
0.45 \\
0.77 \\
0.38\end{array}$ & $\begin{array}{l}\text { I } \ldots \ldots \\
\text { I } \ldots \ldots \\
\text { II } \ldots \ldots \\
\text { I } \ldots \ldots \\
\text { II } \ldots . \\
\text { II } \ldots \ldots \\
\text { I } \ldots \ldots\end{array}$ & $\begin{array}{l}2 \\
2 \\
2 \\
3 \\
2 \\
3 \\
4\end{array}$ & \begin{tabular}{|r}
24,000 \\
68,800 \\
143,500 \\
285,700 \\
393,000 \\
462,700 \\
666,000
\end{tabular} & $\begin{array}{l}1.57 \\
0.66 \\
0.38 \\
0.96 \\
\\
\\
\\
0.41 \\
0.08\end{array}$ & $\begin{array}{l}5.02 \\
1.67 \\
1.27 \\
1.13 \\
0.93 \\
\\
0.42\end{array}$ \\
\hline
\end{tabular}

* c. mm. $\mathrm{O}_{2}$ consumed per 2 cc. blood cell concentration (in thousands) $\times$ time (hours)

$\frac{\dagger \mathrm{mgm} \text {. sugar per hour per } 2 \mathrm{cc} \text {. blood }}{\text { cell concentration (in thousands) }}$.

respiration of the leucocytes. In Table $\mathrm{V}$ the cases have been arranged according to their erythrocyte counts. In a group of the myeloid cases of which the average red cell count was 2.8 million and the leucocyte count $12,109, K_{1}$ and $K_{2}$ were 7.19 and 5.98 respectively, as contrasted to another series in which the red count averaged 4.6 million and the white cells 16,590 , where $K_{1}$ was 6.31 and $K_{2}, 4.36$. The differences in these oxygen constants were no greater than would be expected in view of the differences in the leucocyte counts. Essentially the same is true for the other groups tabulated. One must conclude that with our present methods of study any influence exercised by the red blood cells on the metabolism of leucocytes, if present, cannot be determined. 


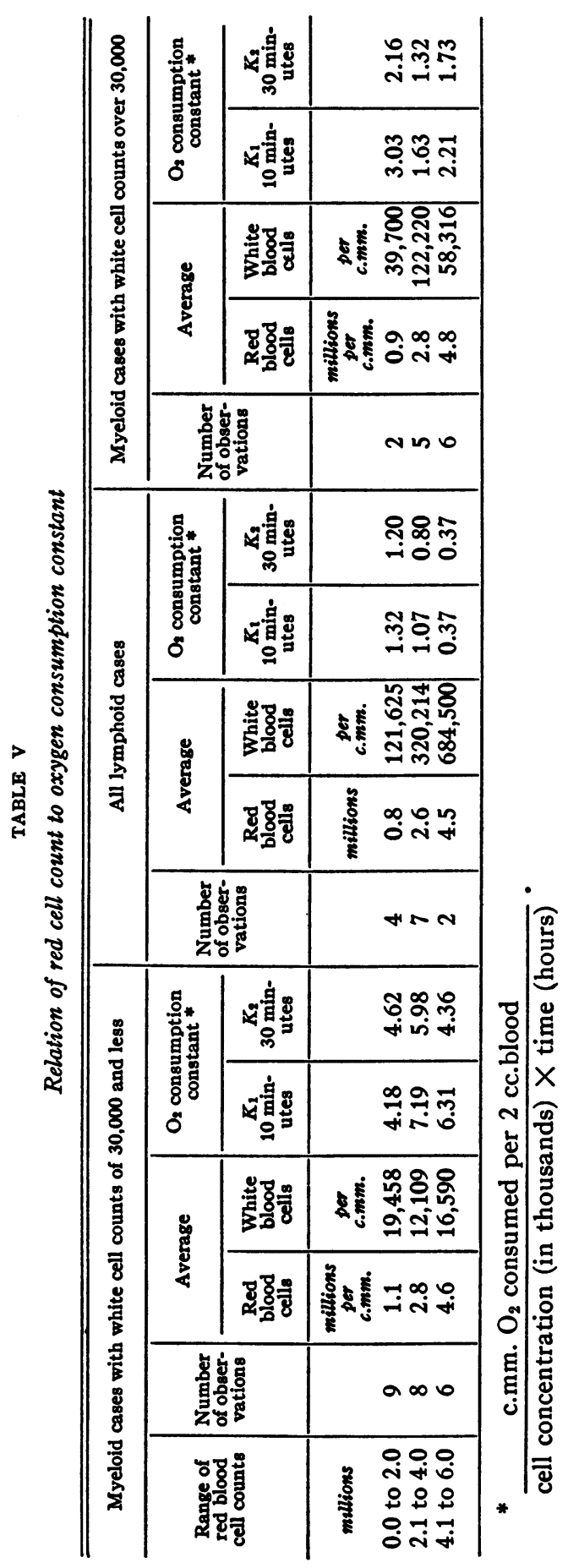


DISCUSSION

Our observations, as described in this paper, show definitely the important part that concentration plays in the "in vitro" metabolism of leucocytes. Their oxygen consumption and aerobic and anaerobic glycolysis are inversely proportional to the number of white blood cells present. The glycolytic function is not as markedly affected as is respiration, and this may perhaps be explained by the general observation that glycolysis is less easily influenced by external factors. Our results fail to substantiate the views advanced by Daland and Isaacs (4) and by Glover, Daland and Schmitz (5) concerning the influence of maturity of the cells on their metabolism. In fact, their results are more plausibly explained on the basis of concentration than on that of maturity. If the age of the leucocyte is a factor in determining its oxygen consumption and glycolysis, its influence is entirely obscured by the effect of concentration, and can hardly be determined with our present methods.

Warburg (9) has demonstrated the difference in metabolism of various types of tissues. Malignant tumors destroy large amounts of sugar aerobically and anaerobically while they consume moderate amounts of oxygen. In contrast to this type of metabolic activity normal adult tissues with the exception of retina have a comparatively small aerobic and anaerobic glycolysis with a high respiratory function. Embryonic tissues assume an intermediate rôle, their aerobic glycolysis being small while the anaerobic glycolysis is quite pronounced. The oxygen consumption of embryonic tissues is similar to that of normal adult tissues but higher than that of malignant tumors. According to Bakker (10) who worked with polynuclear and mononuclear cells obtained from sterile rabbit peritoneal exudates, these cells behave in their metabolism like cancer cells. Fujita (7) on the other hand, working with rats' blood found that the leucocytes have a metabolism similar to that of embryonic tissue. Fleischmann and Kubowitz (11) used goose and rabbit leucocytes suspended in Ringers' solution and found their metabolism to resemble that of malignant tissues.

Our results indicate that the granulocytes of both the leukemic and leucocytic group with their comparatively large aerobic and anaerobic glycolysis resemble malignant tissues in their metabolism, whereas lymphocytes from cases of lymphatic leukemia are similar in their metabolic activity to that of normal adult tissues.

\section{SUMMARY}

Oxygen consumption and aerobic and anaerobic glycolysis of leucocytes have been studied in a series of cases of leucocytosis, and acute and chronic myeloid and lymphoid leukemia. In all 84 experiments were carried out, of which 23 were in cases of leucocytosis, 36 in myeloid leukemia and 25 in lymphoid leukemia. These represent a wide range of leucocyte counts and varying degrees of white cell maturity. 


\section{CONCLUSIONS}

1. The oxygen consumption and glycolytic activity of leucocytes from normal and leukemic blood is, in vitro, inversely proportional to the concentration of the white cells in the blood.

2. The amount of oxygen consumed rapidly decreases the longer the duration of the experiment. The maximum oxygen consumption per unit of time is reached during the first 10 minutes.

3. When allowance was made for the influence of concentration no differences in the metabolism of mature and immature leucocytes could be observed nor between that of leucocytes from normal as compared with leukemic blood.

4. The oxygen consumption of granulocytes is somewhat greater than that of lymphocytes, while the former have a glycolytic power about twice as great as the latter.

5. The number of red blood cells in the sample did not appear to influence the oxygen consumption of the leucocytes.

6. The metabolism of granulocytes under aerobic and anaerobic conditions resembles that of malignant tissues, while that of lymphocytes is similar to the metabolism of normal adult tissues.

We wish to acknowledge the valuable technical assistance of $\mathrm{J}$. Walter Landsberg and Mrs. Florence White.

\section{BIBLIOGRAPHY}

1. Grafe, E., Deutsches Arch. f. klin. Med., 1911, cii, 406. Die Steigerung des Stoff wechsels bei chronischer Leukämie und ihre Ursachen.

2. Levene, P. A., and Meyer, G. M., J. Biol. Chem., 1912, xii, 265. On the Action of Leucocytes on Glucose.

3. Maclean, H., and Weir, H. B., Biochem. J., 1915, ix, 412. The Part Played by the Different Blood Elements in Glycolysis.

4. Daland, G. A., and Isaacs, R., J. Exp. Med., 1927, xlvi, 53. Cell Respiration Studies: II. A Comparative Study of the Oxygen Consumption of Blood from Normal Individuals and Patients with Increased Leucocyte Counts (Sepsis, Chronic Myelogenous Leukemia).

5. Glover, E. C., Daland, G. A., and Schmitz, H. L. Arch. Int. Med., 1930, xlvi, 46. The Metabolism of Normal and Leukemic Leucocytes.

6. Barron, E. S. G., and Harrop, G. A., Jr., J. Biol. Chem., 1929, lxxxiv, 89. Studies on Blood Cell Metabolism. V. The Metabolism of Leucocytes.

7. Fujita, A., Klin. Wchnschr., 1928, vii, 897. Über den Stoff wechsel der Weissen Blutzellen.

8. Harrop, G. A., Jr., Arch. Int. Med., 1919, xxiii, 745. The Oxygen Consumption of Human Erythrocytes.

9. Warburg, O., Ueber den Stoff wechsel der Tumoren. Julius Springer, Berlin, 1926.

10. Bakker, A., Klin. Wchnschr., 1927, vi, 252. Einige Überunstimmungen im Stoff wechsel der carcinomzellen und Exsudatleukocyten.

11. Fleischmann, W., and Kubowitz, F., Biochem. Ztschr., 1927, clxxxi, 395. Über den Stoff wechsel der Leucocyten.

12. Wiseman, B. K., J. Exp. Med., 1931, liv, 271. Criteria of the Age of Lymphocytes in the Peripheral Blood. 